\title{
A Case of Adenosquamous Carcinoma of the Posterior Occipital Scalp
}

\author{
Joon Seok Ko ${ }^{1}$, Jin Pyeong Kim ${ }^{1,2}$, Jung Je Park ${ }^{1,2}$ and Seung Hoon Woo ${ }^{1,2}$ \\ ${ }^{1}$ Departments of Otorhinolaryngology-Head and Neck Surgery, ${ }^{2}$ Institute of Health Sciences, School of Medicine, \\ Gyeongsang National University, Jinju, Korea
}

\section{후두부 피부에 발생한 선편평세포암종 1예}

고준석 ${ }^{1} \cdot$ 김진평 ${ }^{1,2} \cdot$ 박정제 $^{1,2} \cdot$ 우승훈 ${ }^{1,2}$

경상대학교 의학전문대학원 이비인후과학교실, ${ }^{1}$ 건강과학연구원 ${ }^{2}$

\author{
Received October 29, 2011 \\ Revised December 16, 2011 \\ Accepted December 22, 2011 \\ Address for correspondence \\ Seung Hoon Woo, MD \\ Department of Otorhinolaryngology- \\ Head and Neck Surgery, \\ School of Medicine, Gyeongsang \\ National University, 79 Gangnam-ro, \\ Jinju 660-702, Korea \\ Tel $+82-55-750-8173$ \\ Fax +82-55-759-0613 \\ E-mail lesaby@hanmail.net
}

Primary cutaneous adenosquamous carcinomas are very rare with only few published reports. The histopathologic finding consists of two different components - mucin secreting cells (adenocarcinoma) and squamous cells (squamous cell carcinoma). We experienced a case of occipital scalp adenosquamous carcinoma, which is an extremely rare neoplasm in scalp. The lesion is histologically distinctive because of the presence of mixed areas of unequivocal adenocarcinoma and squamous cell carcinoma. It is found that combined surgery and additional radiation therapy is necessary because the biological behavior and prognosis of this neoplasm are considered as more aggressive and worse than that of conventional squamous cell carcinoma.

Korean J Otorhinolaryngol-Head Neck Surg 2012;55:123-7

Key Words Skin neoplasms · Carcinoma · Adenosquamous · Extended posterolateral neck dissection.

\section{서 론}

선편평세포암종은 선암과 편평세포암의 두 암성분이 혼재 되어 있는 악성 종양으로, 주로 자궁, 난소, 위, 장 등에 발생 하며, 드물게 피부에 나타나기도 한다. ${ }^{1-4)}$ 전이, 침윤성이 강하 여 다른 악성종양에 비해 예후가 불량하다. ${ }^{2}$ 방사선 치료에 저 항성을 나타내며, 다발성 경향을 보이고, 국소적인 절제술만 으로는 짧은 기간 내 재발하기 때문에 좀 더 완전하고 광범위 하게 제거하는 것이 필요하며, 수술 후 방사선 치료의 복합적 인 치료방법이 필요하다.

두피(scalp)에 발생한 암종 중 양측 외이도를 연결하는 관상 면(coronal section) 후방의 두피에 발생하는 피부암종의 경우, 일차적으로 경부의 이개 후 림프절(retroauricular lymph node) 과 후두하 림프절(suboccipital node)로, 이차적으로 경부의 후삼각(posterior triangle)으로 전이한다. 따라서 기존의 경부
절제술에 추가하여 상기 언급된 림프절과 후삼각의 림프절, 경정맥 림프절을 함께 일괴로 절제하여야 한다. ${ }^{7-9)}$

저자들은 후두부 두피에 발생한 선편평세포암종으로 광범 위 절제술과 후외측 경부절제술(posterolateral neck dissection)을 시행한 증례를 경험하여, 문헌 고찰과 함께 보고하는 바이다.

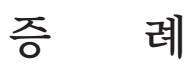

52세 남자 환자가 우연히 발견된 우측 경부 종물을 주소로 본원 이비인후과를 방문하였다. 당뇨 외 특이 기저질환 없는 환자로 본원 성형외과에서 시행한 우측 후두부 피부 병변 조 직 생검(punch biopsy) 결과 선편평상피세포암종으로 진단되 어 이에 대해 수술을 계획하던 중 우측 경부 종물에 대해 본 과로 협진 의뢰되었다. 이학적 검사상 후두부 피부 병변은 
$1.0 \times 1.0 \mathrm{~cm}$ 으로 크기가 작았으나 우측 후경부에 전이성 임 파선으로 의심되는 약 $1 \mathrm{~cm}$ 크기의 경부 종물이 2 개 이상 촉 지되었다. 경부 종물은 단단하고 무통성이었으며, 피부 아래 고정된 소견이었다. 외래에서 시행한 임파선 세침흡인검사 (fine needle aspiration) 결과 전이성 편평상피세포암종의 소 견이 의심되어 경부전산화단층촬영(neck CT), 골 스캔(bone scan), 양전자방출단층촬영(positron emission tomographycomputed tomography, PET-CT), 복부 초음파, 상부 위장 관 내시경 등을 시행하였다. 경부전산화단층촬영에서 우측 후이개, 이하선 하부, 후경부에 전이가 의심되는 임파선이 보였 고(Fig. 1), PET-CT에서 우측 경부(우측 level V, infraparotid area)에 흡수율 증가(hot-uptake) 소견을 보여(Fig. 2) 수술 을 계획하였다. 수술 범위는 원발 부위의 광범위 절제술 및 우 측 선택적 경부절제술(selective neck dissection - 우측 level $\mathrm{II} \sim \mathrm{V}$, retro-auricular, suboccipital)과 피부 이식(skin graft) 을 계획하였다.

환자의 자세를 앙와위(supine position)로 취한 후 두경부 를 병소의 반대쪽으로 외전하여 우측 후두부가 충분히 노출 되도록 준비하였다. 종양의 절제연은 후두부의 조직검사에 의한 반흔을 포함할 수 있고, 각 방향으로 최소 $1 \mathrm{~cm}$ 이상의 안전변연(safety margin)을 취하기 위해 $3 \times 3 \mathrm{~cm}$ 의 타원형의 피부절개를 가한 후 이 타원의 외하측에 연결하여 전경부에 달하도록 수직, 수평절개를 가하였다. 광경근하부(subplatysmal plane)로 피판을 올린 후 경부곽청은 경정맥림프절에서 시작하여 후두부쪽으로 진행하였다. 경부곽청시료와 종괴를 일괴로 절제하고 안전거리를 두기 위하여 하후두부의 근육 일 부를 같이 절제하였다. 더불어 경정맥을 제외한 흥쇄유돌근 과 부신경을 침범하고 있어 경정맥을 제외한 흉쇄유돌근과 부신경을 모두 절제하였다(Fig. 3). 수술소견상 후두골막은 정상이었고, 골파괴 소견도 없었다. 종괴는 일괴로 절제가 가능 하였으며 절제연은 모두 음성이었다.

수술 후 남은 피부의 결손은 부분층 피부 이식(공여부 : 대 퇴부)을 시행하였다. 술 후 병리조직 검사상 우측 후이개, 이 하선 하부, level V의 경정맥 림프절로의 전이가 관찰되었다. 종 괴는 조직검사결과 선암종(adenocarcinoma)의 영역과 편평 상피세포암종(squamous cell carcinoma)의 영역이 공존하는 선편평암종(adenosquamous carcinoma)의 소견을 보였다 (Fig. 4). 추가로 실시한 periodic acid-schiff(PAS) 염색상에 서 부분 양성으로 점액생성세포를 관찰할 수 있었으며, high molecular weight cytokeratin 양성, P63 염색에서 편평상피

Fig. 1. The post-contrast enhanced neck CT. Each arrow shows the main mass and metastatic neck nodes. Axial view - scalp adenosquamous carcinoma (A). Axial view - deep suboccipital lymph node (B). Coronal view - retro-auricular and level $\checkmark$ lymph node (C). Coronal view - infra parotid lymph node (D).
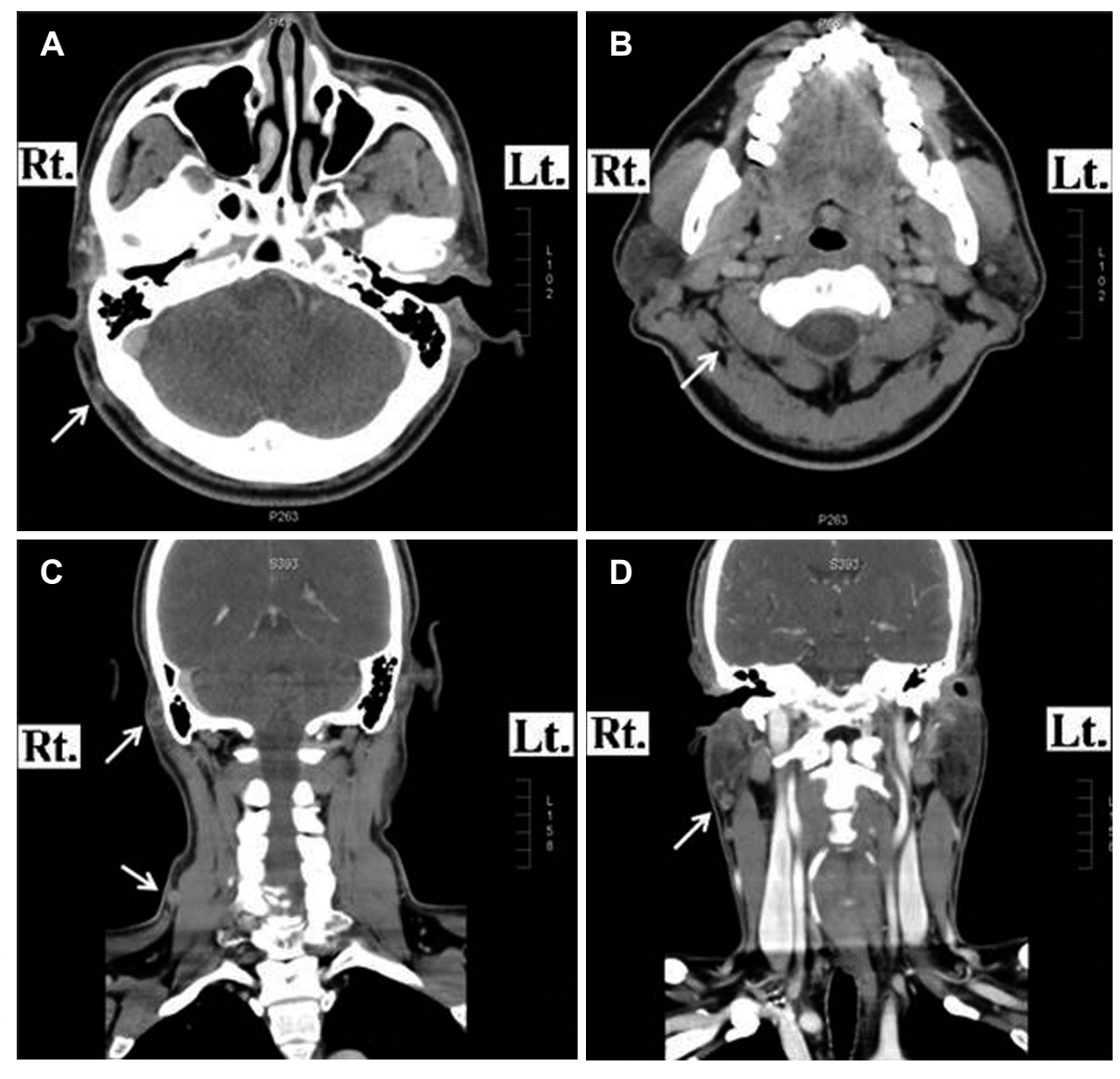
세포암종 부분에만 염색되는 전형적인 모습을 보여 선편평세 포암종으로 진단되었다(Fig. 5). 기질의 유리화(stromal hya- linization), 석회화, 괴사 등의 소견은 있었으나 림프관이나 혈 관 등 주위조직으로의 침습은 보이지 않았다. 환자는 술 후
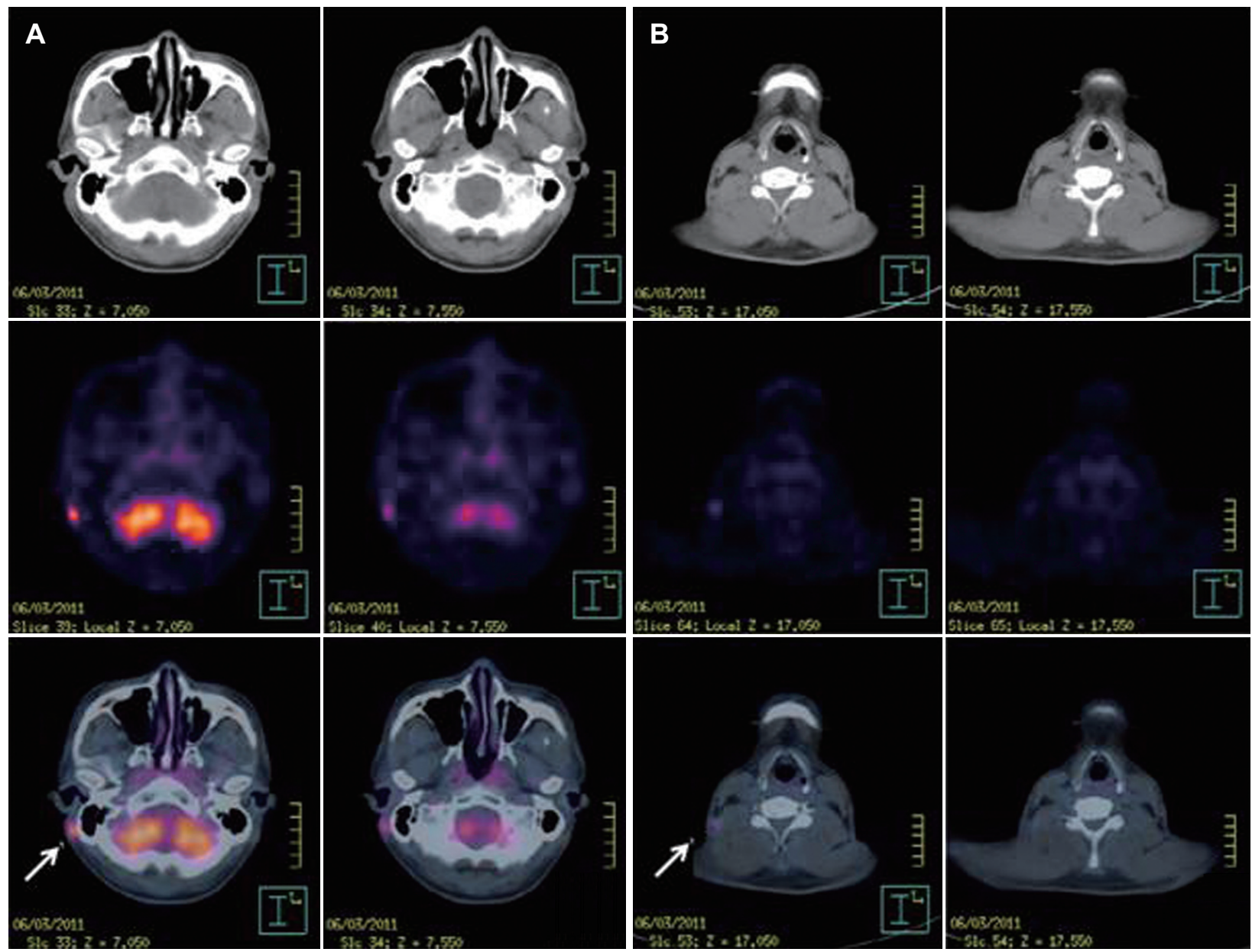

Fig. 2. The PET-CT of the same patient. Each arrow shows the main mass and metastatic neck nodes. Main mass (A). Level $V$ lymph node (B). PET-CT: positron emission tomography-computed tomography.

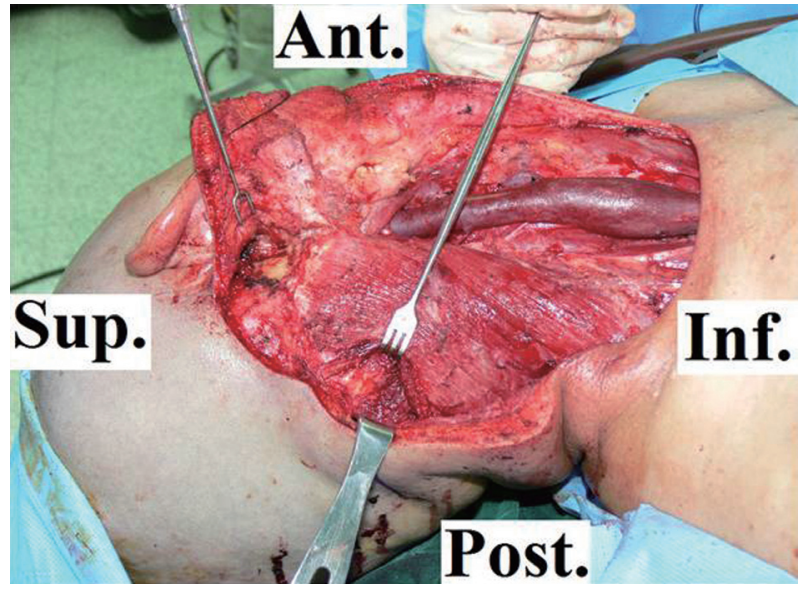

Fig. 3. Postoperative photography was taken after wide excision of main mass with posterolateral neck dissection. Photography shows the operational view after traction of Splenius capitus muscle, cutting the SCM muscle, dissection of retroauricular node, suboccipital node, infra parotid node and level II-V. SCM: sternocleidomastoid.

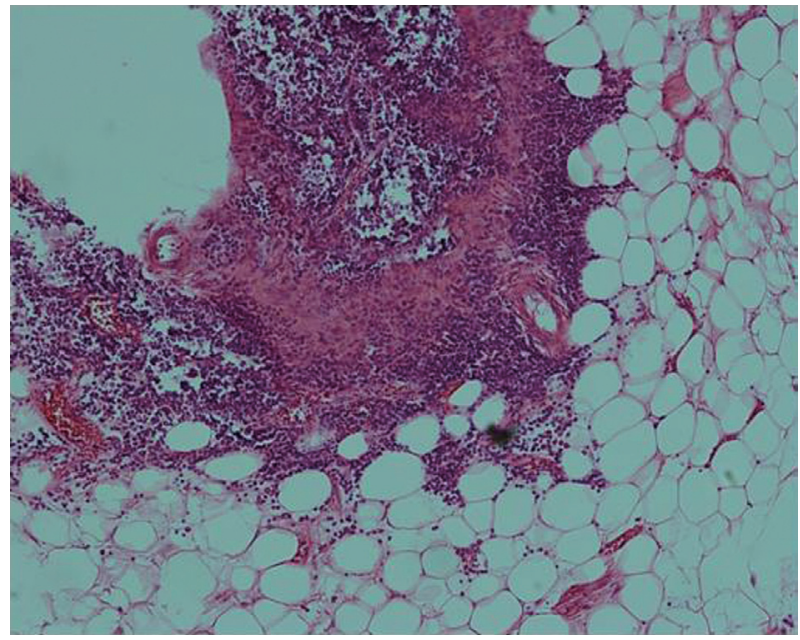

Fig. 4. Microscopic image of the main mass. This picture shows that squamous cell tumor nest with keratinization, gland formation by goblet cells and stromal response $(\mathrm{H} \& \mathrm{E}, \times 100)$. 


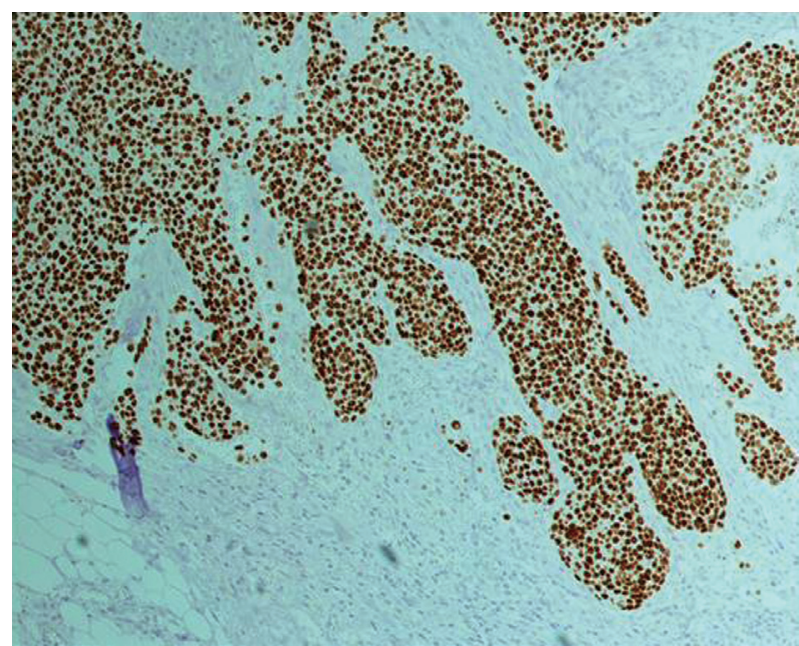

Fig. 5. Microscopic image of the main mass. The special staining photo shows that positive staining of squamous carcinoma cells for P63 (brown color) and adenocarcinoma cell nests negative for P63 (P63, × 100).

10 일째 퇴원하였고, 6주간 방사선 치료와 병용하여 cisplantin 을 이용한 항암 치료를 시행하였다. 현재 술 후 1 년째 특별한 소견 없이 외래에서 경과 관찰 중이다.

\section{고 찰}

Gerughty 등 5)이 처음으로 선편평세포암종이라는 용어를 사용하였는데, 같은 병소 내에서 선암종과 편평세포암으로 존 재하는 부분이 따로 있고, 혼합된 부분이 동시에 존재하며, 또 PAS 등의 특수 염색으로 선상피세포(glandular epithelium) 내에 점액(sialomucin)의 존재가 증명되어야 한다. 선편평세 포암종의 조직학적 발생기원에 대해서는 3 가지 가설이 있다. ${ }^{6}$ 첫째, 두 개의 다른 종양의 충돌로 발생가능하고, 둘째, 선암 종의 선상피세포의 화생으로 생길 수 있으며, 셋째, 선암종과 편평세포암종이 한 개의 다능세포로부터 발생한다는 것이다.

선편평세포암종은 선양편평세포암종(adenoid squamous cell carcinoma)과 점액상피양암종(mucoepidermoid carcinoma)과의 감별이 필요한데, 이는 조직학적인 도관의 분화, 세포간교의 불확실성과 특수염색(Alcian blue, PAS or Mayer' s mucicarmine)을 통해 감별 진단할 수 있다. 후자의 두 질 환과는 다르게 선편평세포암종은 편평세포암종의 영역과 함 께 선암영역에 분명한 선구조가 존재하고, PAS 염색상에서 점액생성세포를 관찰할 수 있다. ${ }^{5,8)}$ 선양편평세포암종은 편평 세포암종의 아형으로서 가선(pseudogland)을 형성하나 특수 염색(Alcian blue, PAS, or Mayer's mucicarmine)상 점액 생 성을 볼 수 없고, 점액상피양암종은 중간세포, 투명세포 및 점 액 분비세포 등을 특징으로 하는 저등급의 암종으로, 핵등급
이 높고 중간세포가 없다. ${ }^{10)}$ 이 외에도 선상기저세포암, 낭샘 종, 낭샘암, 투명세포암, 전이암 등과의 감별이 필요하다. ${ }^{6}$

보고된 증례수가 적어 치료방법이 명확하게 확립된 것은 아직 없다. 방사선 치료만으로는 저항성을 나타내며, 도관계 깊은 곳에서 기원하여 다발성이고, 국소적인 절제술만으로는 짧은 기간내에 재발하기 때문에 좀 더 완전하고 광범위하게 제거하는 것이 필요하며, 수술 후 방사선 치료의 복합적인 치 료방법이 필요할 것으로 생각된다. ${ }^{5,6,11,12)}$

두피의 전두부에 발생하는 악성종양의 림프절전이는 주로 이하선주위 림프절과 경정맥림프절로 전이되므로 이하선절 제술 및 기존의 경부절제술로 충분하지만, 양측 외이도를 연 결하는 관상면 뒤의 두피에 발생하는 피부암종(malignant skin tumor)의 경부림프절전이에 대한 치료는 기존의 술식만 으로는 충분하지 않다. ${ }^{7,9)}$ 후두부(occipital area)가 원발병소 인 경우 경부림프절전이는 주로 이개후 림프절(retroauricular lymph node)과 후두하 림프절(suboccipital node)로 전이된 후, 경부의 후삼각(posterior triangle)으로 전이되므로 상기 림프절을 포함하고 후삼각의 림프절과 경정맥림프절을 함께 절제하여야 하며, 이를 후외측경부절제술(posterolateral neck dissection)이라 한다. 즉, 후외측경부절제술에서 제거되는 구 조는 경부 level II, III, IV, V의 림프절과 표층 및 심층 후두 하림프절, 이개후림프절, 그리고 승모근의 상부이다.,8)

원발병소의 위치에 따라 상기 관상면의 중앙에 위치하거나 이에 가까운 경우에는 기존의 경부곽청술과 더불어 후외측경 부곽청술을 동시에 시행할 수도 있다. 흥쇄유돌근, 경정맥, 그 리고 부신경의 절제여부는 전이림프절의 크기, 위치 및 범위 에 따라 다르다.

저자들은 후두부 피부암종의 경부 임파선 전이한 환자의 경 우에서 광범위 절제술과 후외측 경부절제술(posterolateral neck dissection)을 시행하였고, 조직검사 결과 두경부 영역에 서 드물게 발생하는 선편평세포암종을 경험하여, 문헌 고찰 과 함께 보고하는 바이다.

\section{REFERENCES}

1) Weidner N, Foucar E. Adenosquamous carcinoma of the skin. An aggressive mucin- and gland-forming squamous carcinoma. Arch Dermatol 1985;121(6):775-9.

2) Urban A, Oszacki J, Szczygiel K. Squamous cell metaplasia in carcinoma of the stomach. Acta Med Pol 1966;7(3):227-43.

3) Choi CY, Chung JB, An MS, Koh KS, Lim HJ. A case of adenosquamous carcinoma of the larynx. Korean J Otolaryngol-Head Neck Surg 1987;30(1):165-8.

4) Kim YM, Kim KS, Lee JY, Chu YC. A case of adenosquamous' carcinoma of the larynx. Korean J Otolaryngol-Head Neck Surg 1993; 36(6):1349-55.

5) Gerughty RM, Hennigar GR, Brown FM. Adenosquamous carcinoma of the nasal, oral and laryngeal cavities. A clinicopathologic survey of ten cases. Cancer 1968;22(6):1140-55. 
6) Fujino K, Ito J, Kanaji M, Shiomi Y, Saiga T. Adenosquamous carcinoma of the larynx. Am J Otolaryngol 1995;16(2):115-8.

7) Choi EC, Koh YW, Lee SY, Kim HJ, Kim DY. A case of recurred squamous cell carcinoma on scalp using a extended posterolateral neck dissection. Korean J Otolaryngol-Head Neck Surg 1999;42(5): 664-8.

8) de Langen ZJ, Vermey A. Posterolateral neck dissection. Head Neck Surg 1988;10(4):252-6.

9) Rochlin DB. Posterolateral neck dissection for malignant neoplasms. Surg Gynecol Obstet 1962;115:369-73.
10) Damiani JM, Damiani KK, Hauck K, Hyams VJ. Mucoepidermoidadenosquamous carcinoma of the larynx and hypopharynx: a report of 21 cases and a review of the literature. Otolaryngol Head Neck Surg 1981;89(2):235-43.

11) Ferlito A. A pathologic and clinical study of adenosquamous carcinoma of the larynx. Report of four cases and review of the literature. Acta Otorhinolaryngol Belg 1976;30(4):379-89.

12) Fu JM, McCalmont T, Yu SS. Adenosquamous carcinoma of the skin: a case series. Arch Dermatol 2009;145(10):1152-8. 